\title{
The Royal Society of Queensland Award of Life Membership to Craig Walton, 15 June 2021
}

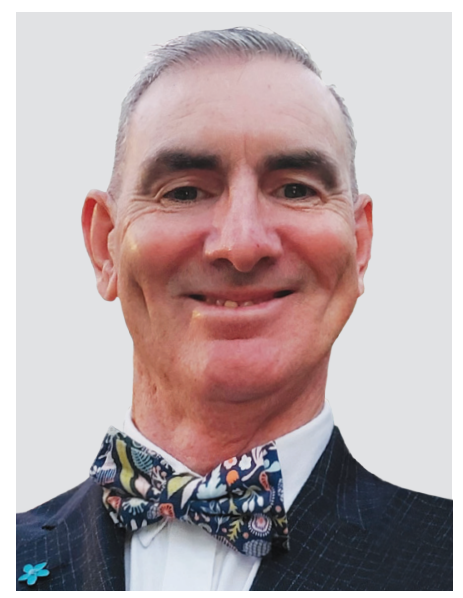

Craig grew up on a small farm at Toodyay in country Western Australia and was immersed in the natural world from an early age. His growing interest in the history of science led to an undergraduate Bachelor of Science degree from the University of Western Australia, majoring in botany and zoology, with honours in botany completed in 1987. This was followed by a Master of Science (Plant Physiology) from the University of Guelph in Canada in 1993.

In his early botanical research Craig focused on pulse crops and salt tolerance of wheat in Western Australia and soybean physiology in Canada, followed by quarantine issues involved in the risk assessment of new plant species in Canberra. In 1999 he moved to Queensland and began a long involvement with the Department of Natural Resources - in its various forms - where he has worked ever since. For six years he was an invasive species ecologist, from which experience he wrote three book chapters (Walton, 1999; Walton, 2001; Walton, 2009). In addition, he has published seven refereed papers and 25 reports and strategies, including nine strategies for Weeds of National Significance and the first Pest Animals Strategy for Australia. He has been a regular speaker at domestic conferences, also travelling to New Zealand, Brazil, South Africa and the United States to present on these topics. His invasive species policy work culminated in the publication of a book on the history of the science of weed biological control in Queensland (Walton, 2005); soon after it was published, the key research station profiled in the book was sold for its real-estate value and much of the history was institutionalised. This research was the topic of his first presentation to The Royal Society of Queensland in 2005.

Craig's interests in the intersection of history and science found a welcome home in his enduring relationship with The Royal Society of Queensland. He was elected Secretary in 1999 and held the role for three years. In addition, as part of this role he was a member of the RSQ Review Panel in 2002.

$\mathrm{He}$ cemented his commitment in 2003 when elected President - enjoying a 10-year term that made him the Society's longest-serving President - overseeing a decade of significant change in both national and state leaderships. He conscientiously and effectively served in this position; then from June 2013 he remained on Council as an active Immediate Past President and mentor to the

and photographs, should be addressed to the Secretary of The Royal Society of Queensland (rsocqld@gmail.com). 
incoming President Geoff Edwards until November 2019 when he retired.

This is a remarkable 20 years of service in an office-bearing position. The Society owes an immense debt of gratitude to Craig for his leadership and contributions.

National cooperation between state societies in the early 2000s saw the Society co-fund a threeyear Eureka Prize and other national initiatives under the national banner, although the Society declined membership of the Royal Societies of Australia in 2008 due to concerns over its constitution and management. National activity waned with the election of the Newman government in 2012, which saw the commencement of cuts to financial incentives to the sciences, as well as cuts to libraries and research bodies involved in science. Craig worked to counteract these changes by promoting cooperation between more than 20 not-for-profit scientific groups in Queensland, including citizen science groups, culminating in the creation of the Queensland Science Network in October 2016.

His belief that anyone could, and should, be involved in science was best demonstrated by his work with Dr Alistair Melzer, the Central Queensland Koala Volunteers and Royal Society members to create a research fund to support projects which escape the attention of the mainstream grant programs. The fund sought to encourage applications for small-scale projects such as those by NGO groups or early-career researchers. After several years of planning and evolution of the funding arrangements, this culminated in the establishment of the RSQ Research Fund, which was launched by the Society's Patron the Governor in June 2014.

Craig has always seen the Proceedings as an enduring legacy of the Society, and his small committee always kept its publication to the fore of Council activities. During his presidency he oversaw the production of two special editions of the Proceedings: Volume 115: Life in a Fire-Prone Environment: Translating Science into Practice (2006) and Volume 117: A Place of Sandhills: Ecology, Hydrogeomorphology and Management of Queensland's Dune Islands (2011).

However, he is most proud of the Queensland
Gambling Fund grant in 2013 that underwrote the digitisation of all the Society's Proceedings back to 1884 , as well as early minute books and other important documents and letters, and the creation of the contemporary RSQ website. By archiving historical records and proceedings in electronic form and then deposition in the State Library and on the web, the early history of the Society lives on and can be accessed.

Craig continues to work in science. During his presidency he moved professional space into strategic water policy, including Queensland statewide responses to both the Millennium Drought - including policy for both the recycled water and demand management programs - and supported responses to the catastrophic weather events of 2011, managing global interest in understanding Queensland's response and a range of international scientific visits. This experience was his foundation for coordinating the Queensland Government's involvement in the International Water Association's World Water Congress - held in Brisbane in 2016 - with over 2000 Congress registrations and participants from 108 countries. More recently, his professional interests have centred on water management in the Great Artesian Basin, assisting communities to make the Basin watertight through funding programs, education and research. $\mathrm{He}$ is currently policy advisor to both the state Ministerial Advisory Council and the equivalent national body. In 2020 he served on the editorial panel of the Society's Proceedings Vol. 126 (Springs of the Great Artesian Basin).

As a Principal Policy Officer, among other roles in the Queensland Department of Natural Resources and Mines, he has made a significant professional contribution to natural resource policy, planning and management, initially in terrestrial ecosystems and more recently in water resources. These contributions would by themselves warrant an award for high achievement in science. However, it is for his immensely valuable service to the Society over more than 20 years that Council without hesitation resolved to offer him its highest award. The President and Council of The Royal Society of Queensland congratulate Mr Craig Walton on his outstanding career and honour him with its highest award, that of Life Membership. 


\section{Publications}

Abott, D. G., Witkowski, E. T. F., Lamont, B. B., \& Walton, C. S. (1991). Conservation biology of the gazetted rare species, Banksia goodii, and its abundant co-occurring Banksia gardnerii. Report to the Australian Parks and Wildlife Service.

Arthington, A. H., Jackson, S. E., Tomlinson, M., Walton, C. S., Rossini, R. A., \& Flook, S. C. (2020). Oases of life in Australia's arid and semi-arid interior. Proceedings of The Royal Society of Queensland, 126 (Springs of the Great Artesian Basin), 1-10.

Csurhes, S., Walton, C. S., \& Leigh, C. (2009). African lovegrass in Queensland. Pest Status Review Series. Queensland Department of Natural Resources and Mines.

Kuiper, P. J., Walton, C. S., \& Greenway, H. (1994). Effect of hypoxia on ion uptake of nodal and seminal roots of wheat: Measured in a split-root system. Plant Physiology and Biochemistry, 32(2), 267-276.

O'Keeffe, M. S., \& Walton, C. S. (2001). Vertebrate pests in Queensland. Pest Status Review Series. Queensland Department of Natural Resources and Mines.

Oliver, J., \& Walton. C. (2004). Pests in Queensland baseline survey 2003: A survey of primary producers and residents of regional centres and large country towns. Queensland Department of Natural Resources, Mines and Energy.

Raghu, S., \& Walton, C. (2007). Understanding the ghost of cactoblastis past: Historical clarifications of a poster child of classical biological control. Bioscience 57(8), 699-705. https://doi.org/10.1641/B570810

Rossini, R. A., Arthington, A. H., Jackson, S. E., Tomlinson, M., Walton, C. S., \& Flook, S. C. (2020). Knowledge gaps and future directions for research, management and conservation. Proceedings of The Royal Society of Queensland, 126 (Springs of the Great Artesian Basin), 305-322.

Shelp, B. J., Walton, C. S., Snedden, S., Tuin, L., Oresnik, I. J., \& Layzell, D. B. (1995). Gaba shunt in developing soybean seeds is associated with hypoxia. Physiologia Plantarum, 94, 219-228. https://doi. org/10.1111/j.1399-3054.1995.tb05304.x

Steinke, E., \& Walton, C. S. (1999). Weed risk assessment of plant imports to Australia: Policy and process. Australian Journal of Environmental Management, 6(3), 157-163. https://doi.org/10.1080/14 486563.1999.10648464

Van der Moezel, P. G., Walton, C. S., Pearce-Pinto, G. V. N., \& Bell, D. T. (1989). Screening for salinity and waterlogging tolerance in five Casuarina species. Landscape and Urban Planning, 17, 331-337. https://doi.org/10.1016/0169-2046(89)90087-X

Walton, C. S. (1991). The bad Banksias of the bush - Australia's most recognisable plant. Curtin Gazette, 4(3), 11-14.

Walton, C. S. (1998). Preventing the introduction of potential weeds as ornamental plants. The Nursery Papers, Issue 1998/010.

Walton, C. S. (1998). Tracking weeds around the world. Australian Quarantine and Inspection Bulletin.

Walton, C. S. (1998). A new approach for plant imports. Weeds Australia, 1(2).

Walton, C. S. (1999, February). Invasive plants - A global issue. Australian Nursery Manager.

Walton, C. S. (1999). Cabomba caroliniana. In F. D. Panetta, R. H. Groves, \& R. C. H. Shepherd (Eds.), The Biology of Australia Weeds (Vol. 2). R.G. and F.J. Richardson.

Walton, C. S. (2001). Implementation of a permitted list approach to plant introduction in Australia. In R. H. Groves, F. D. Panetta, \& J. G. Virtue (Eds.), Weed Risk Assessment (pp. 93-99). CSIRO Publishing.

Walton, C. S. (Ed.). (2001-2002). Rubber vine, Prickly acacia, Parkinsonia, Mesquite, Parthenium weed, Cabomba, Lantana, Pond apple and Cabomba. Weeds of National Significance Strategies. Australian Department of Agriculture. 
Walton, C. S. (2003). Leucaena (Leucaena leucocephala) in Queensland. Pest Status Review Series. Queensland Department of Natural Resources and Mines.

Walton, C. S. (2004). Leucaena leucocephala (Lamark) de Wit. Plant Protection Quarterly, 18(3), 90-98.

Walton, C. (2005). Reclaiming lost provinces: A century of weed biological control in Queensland. Queensland Department of Natural Resources and Mines.

Walton, C. S. (2009). Leucaena leucocephala. In F. D. Panetta (Ed.), The biology of Australia weeds (Vol. 3). R.G. \& F.J. Richardson.

Walton, C. S. (2020). Obituary for Lynn Brake. Proceedings of The Royal Society of Queensland, 126, 323-324.

Walton, C. S., Hardwick, L., \& Hanson, J. (2003). Locusts in Queensland. Pest Status Review Series. Queensland Department of Natural Resources and Mines.

Walton, C. S., \& Kullmann, K. W. (1994). Distribution and density of perennial veld grass (Ehrharta calycina) within Kings Park (Report to Kings Park Board). Botanic Gardens and Parks Authority, Western Australia.

Walton, C. S., \& Leigh, C. (2004). Lippia in Queensland. Pest Status Review Series. Queensland Department of Natural Resources and Mines.

Walton, C. S., \& Elliott, H. (2003). Weeds of Southern Queensland: Research priorities (Internal Report). Queensland Department of Natural Resources and Mines.

Walton, C. S. (2001). National Weedy Sporobolus Grasses Strategy. Queensland Department of Natural Resources and Mines and Weedy Sporobolus Grasses Management Group.

Witkowski, E. T. F., Lamont, B. B., Walton, C. S., \& Radford, S. (1992). Leaf demography, sclerophylly and ecophysiology of Banksia petiolaris and B. baueri. Australian Journal of Botany, 40(6), 849-862. https://doi.org/10.1071/BT9920849

Witkowski, E. T. F., Lamont, B. B., Walton, C. S., \& Radford, S. (1992). Leaf demography, sclerophylly and ecophysiology of two Banksias with contrasting leaf life spans. Australian Journal of Botany, 40, 849-862. https://doi.org/10.1071/BT9920849

Council of The Royal Society of Queensland (2021). The Royal Society of Queensland, Award of Life Membership to Craig Walton, 15 June 2021. Proceedings of The Royal Society of Queensland, 129, x-xx. https://doi.org/10.53060/ prsq.2021.c1 